\title{
The prosthetic management of gingival aesthetics
}

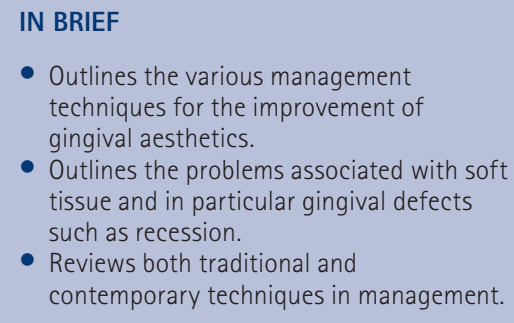

- Outlines the various management techniques for the improvement of gingival aesthetics.

Outlines the problems associated with soft tissue and in particular gingival defects contemporary techniques in management.

Periodontal disease, trauma, and congenital defects can result in both soft tissue and hard tissue defects that can present with aesthetic problems. The management of these problems may be limited to prevention or surgical management which can result in significant morbidity especially if a second surgical site for grafting is utilised. This article describes the various prosthodontic techniques to improve gingival aesthetics using contemporary materials such as gingivally coloured composite and gingivally coloured porcelain in addition to more traditional materials such as standard prosthetic acrylic.

\section{INTRODUCTION}

The preservation or reproduction of optimal mucogingival aesthetics can be difficult to achieve from both a surgical and prosthetic perspective. An increasing patient and clinician awareness of the importance of gingival and smile aesthetics has resulted in the development of both surgical and prosthetic techniques aimed at improving or maintaining these aesthetic characteristics. ${ }^{1,2}$

Unsightly recession defects may present with concomitant buccal cervical cavities which may require restoration to protect from further tooth surface loss, reduce plaque retention or decrease dentinal sensitivity. Where recession is more generalised and especially in those patients who have undergone successful periodontal therapy, the loss of papillae may also be unsightly and the term 'black triangle syndrome' has been coined. ${ }^{3}$ The maintenance of papillae after extraction can be difficult especially where heavily restored teeth, trauma or congenital conditions present with both

${ }^{1 *} \mathrm{SpR}$ in Restorative Dentistry, ${ }^{2} \mathrm{SpR}$ in Restorative Dentistry, ${ }^{3}$ Consultant in Restorative Dentistry, Department of Prosthodontics, Newcastle Dental Hospital,

Richardson Road, Newcastle NE2 4AZ

${ }^{*}$ Correspondence to: Dr Aws Alani

Email:awsalani@hotmail.com

\section{Refereed Paper}

Accepted 4 November 2010

DOI: 10.1038/sj.bdj.2011.2

${ }^{\circledR}$ British Dental Journal 2011; 210: 63-69 compromised quality and quantity of bone and soft tissues. Surgical techniques advocated for recreating gingival architecture around recession or alveolar defects are technique-sensitive and may require a graft from an additional surgical site with consequent additional morbidity. ${ }^{4}$ Where edentulous spaces present with marked vertical and horizontal defects bone grafting may be required to support implant rehabilitation especially in the aesthetic zone. ${ }^{5}$ If patients are keen to improve these aspects, the surgical option may be presented without much alternative.

Matching gingival and tooth proportions by either fixed or removable means to achieve aesthetic harmony to the smile can be challenging (Figs 1 and 2). These difficulties are exacerbated where a patient presents with a so-called 'high smile line' exposing differing lengths of teeth in the aesthetic zone. Where there is vertical soft tissue loss in edentulous spaces, a variety of surgical techniques have been advocated to increase soft tissue volume before the provision of a definitive bridge. ${ }^{6,7}$ These techniques are primarily designed to improve the emergence profile of the pontic but as noted, the morbidity of a possible second surgical site is an important consideration.

This paper describes both traditional and contemporary techniques available in the prosthetic management of soft tissue aesthetics and discusses their advantages, disadvantages and alternatives.

\section{MANAGEMENT OF RECESSION ON SINGLE TEETH}

\section{Gingivally coloured restorations on natural teeth}

In situations where recession is localised to a single tooth, the aetiology of the recession must first be identified and addressed before the provision of any restorations. Indeed, patients may not be aware of the recessive defect and remedial measures to stop progression of the recession may suffice. The need to achieve and maintain gingival health is important as the repercussions of gingival disease after restoration can be difficult to manage. Where a buccal cervical restoration is indicated, the aetiology of tooth tissue loss needs to be considered. Untreated non-carious cervical lesions may result in the exposure of root dentine causing hypersensitivity; conversely, carious cervical lesions can progress to pulpal exposure. ${ }^{8,9}$

A relatively new innovation is the use of adhesive materials that are coloured with gingival shades to match adjacent soft tissues. Zalkind and Hochman first described the use of gingivally coloured composites in the management of a cervical defect. ${ }^{10}$ The authors described the need to pay specific attention to the cervical contour of the restoration to prevent plaque retention; this can be achieved using techniques to apply the composite with the appropriate instruments, adequate moisture control and curing. ${ }^{11,12}$ To provide optimal soft tissue aesthetics with adhesive 
materials, a pseudo gingival sulcus can be created around the margin of the restoration coinciding with the previous free gingival margin (Fig. 3). More recently the use of gingival porcelain veneers has been described in a patient with a history of periodontal treatment. ${ }^{13}$ In this case report the presence of gingival recession localised to 11 and 21 was treated with gingivally coloured partial coverage porcelain veneers. A diagnostic procedure was performed using pink wax both intra-orally and on study models to aid in visualising the final result. ${ }^{13}$ The preparation of the teeth included a chamfer margin in combination with a $0.5 \mathrm{~mm}$ labial reduction. ${ }^{13}$ The final restoration was constructed with the aid of an intra-oral photograph as shade matching proved to be difficult. The authors commented that there was a poor shade match in the definitive restoration although at one week review, the patient's symptoms of dentine sensitivity had ceased. ${ }^{13}$

Where there is a developmental cause for mismatch in the proportions of the patient's teeth, the use of gingival porcelain in combination with traditional tooth coloured porcelain can aid in improving individual tooth proportions (Figs 4 and 5). The advantages and disadvantages of gingival porcelain veneers and gingival coloured composite are illustrated in Table 1. Where extracoronal restorations are provided for teeth with recession, gingival porcelain can be incorporated into extracoronal restorations to provide an improved aesthetic result (Figs 6 and 7). ${ }^{10,14}$

\section{Gingivally coloured restorations on implants}

Compromised aesthetics subsequent to loss of peri-implant tissue can be improved by the application of gingival coloured porcelain to the cervical portion of restorations (Figs 8-10). ${ }^{15}$ The use of gingival coloured ceramic in the restoration of single tooth implants has been described for both allceramic crowns and metal-ceramic crown restorations. ${ }^{15}$ One patient in this clinical case report complained of uneven gingival margins after implant provision which was followed by two episodes of mucogingival surgery. The use of gingivally coloured porcelain applied to the cervical region of the definitive crown produced a satisfactory result. In another case described in the same study, gingival porcelain was applied to the custom zirconia abutment as opposed to the cement-over crown. The gingival porcelain in this restoration was ridge-lapped, extending mesially and cervically masking the absence of an interdental papilla in addition to the recession defect at the implant itself. The extent of application of gingivally coloured porcelain toward gingival embrasure spaces may be limited by the need to maintain a path of insertion of the crown in relation to adjacent teeth. In contrast, the application of gingival porcelain to customised abutments allows more scope for gingival embrasure spaces to be filled where interproximal papillae are missing, as there are fewer constraints to the path of insertion of the abutment in comparison to the crown..$^{15}$ This perceived aesthetic advantage needs to be balanced against the likelihood of increased difficulty in keeping the implant-abutment interface plaque-free, and in carrying out peri-implant probing examinations. If the ridge-lap is extensive, the presence of peri-implant problems may not become apparent until the restoration and associated components are completely removed. The authors also commented that the technique could be applicable to those cases where future peri-implant recession is anticipated - although the recognition that this may become more likely with a restoration that was not readily cleansable was not identified. An advantage of such a technique is the relocation of the cement lute away from the soft tissues. ${ }^{15}$ This needs to be balanced against the possibility of a visible cement line at the crown-abutment interface in addition to the increased technical difficulty in making the custom abutment and definitive restoration.

\section{MANAGEMENT OF SOFT TISSUE AESTHETICS FOR MULTIPLE TEETH AND EDENTULOUS SPANS}

\section{Gingival prosthesis}

Where there is generalised tissue loss as a result of periodontal disease (Figs 12-14) or where there is significant variation in gingival margin heights (Figs 15 and 16), the use of a 'gingival prosthesis' can dramatically improve aesthetics especially in those patients with a high smile line. ${ }^{16}$ This form of prosthesis can also be used in situations where soft tissue has been lost

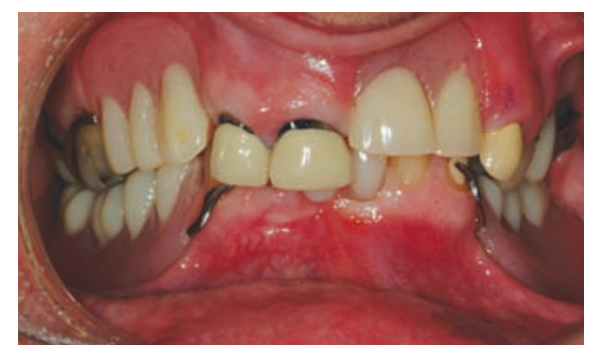

Fig. 1 Gingival height discrepancy between natural teeth and the removable partial denture

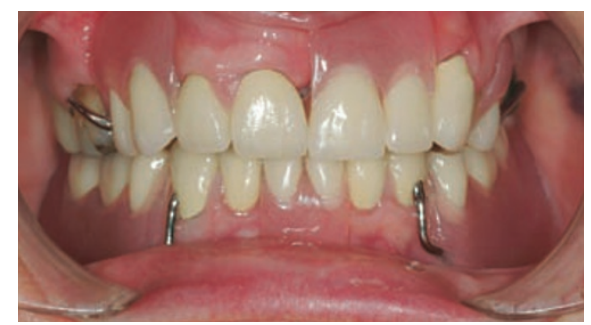

Fig. 2 Post-treatment view showing harmony in gingival levels. Treatment involved crown lengthening procedures on 11, 12, and 23, new crowns and the provision of a new denture. (Courtesy of Suresh Nayar, Consultant in Restorative Dentistry, Hull Royal Infirmary)

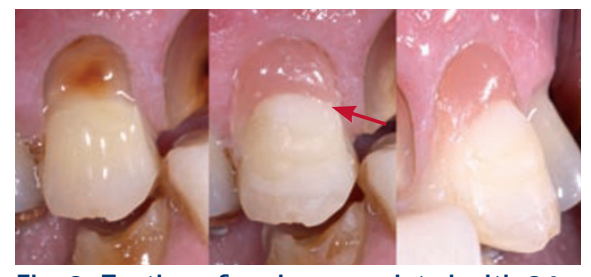

Fig. 3 Tooth surface loss associated with 24. Cervical dimensions recreated with toothcoloured composite followed by gingivally coloured composite. Note the red arrow denoting the 'pseudo-gingival sulcus'

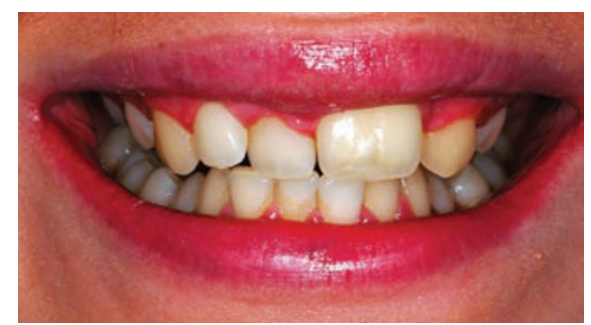

Fig. 4 Patient presenting with a megadont (21 site) and congenitally missing 22

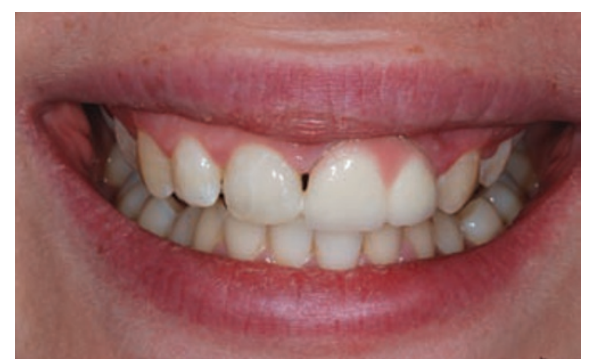

Fig. 5 Once orthodontic realignment was completed a veneer was placed on the megadont. This incorporated gingivally coloured porcelain cervically to facilitate the masking of the tooth to resemble two separate units 
Table 1 Comparison between gingival composite and gingival porcelain for cervical restorations

\begin{tabular}{|c|c|c|}
\hline Feature & Gingivally coloured composite & Gingivally coloured porcelain \\
\hline Fabrication and placement & $\begin{array}{l}\text { Can be challenging due to moisture control when } \\
\text { in close proximity to the gingival sulcus. The } \\
\text { margin of the composite restoration needs } \\
\text { careful consideration to prevent further recession }\end{array}$ & $\begin{array}{l}\text { May require the removal of sound tooth tissue and } \\
\text { production of a margin on root dentine. The marginal } \\
\text { interface of the restoration needs careful consideration } \\
\text { to prevent further recession }\end{array}$ \\
\hline Shape, colour, form and characterisation & $\begin{array}{l}\text { The clinician has direct control over the } \\
\text { shape, colour and the characterisation of the } \\
\text { restoration. Minimally invasive and bond can } \\
\text { be predictable where sound enamel is still } \\
\text { present. Some composite kits include staining } \\
\text { shades that can be used for characterisation }\end{array}$ & $\begin{array}{l}\text { The clinician does not have direct control over the } \\
\text { form of the restoration and so cannot appraise } \\
\text { cleansability of the final restoration and shade. Colour } \\
\text { and characterisation may be difficult to relay to the } \\
\text { technician }\end{array}$ \\
\hline Refurbishment & $\begin{array}{l}\text { Can be removed and replaced with minimal } \\
\text { morbidity to underlying tooth tissue. The } \\
\text { composite can be easily modified post curing } \\
\text { to improve cleansability and characterisation }\end{array}$ & $\begin{array}{l}\text { Difficult to refurbish and the replacement may result } \\
\text { in significant removal of sound tooth tissue which may } \\
\text { also compromise the periodontium }\end{array}$ \\
\hline Hygiene & $\begin{array}{l}\text { The cervical extent of the composite is directly } \\
\text { under the clinician's control. The cleansability } \\
\text { can be evaluated at the time of placement }\end{array}$ & $\begin{array}{l}\text { The cement lute may encroach upon the cervical gingival } \\
\text { margin causing trauma and subsequent plaque retention }\end{array}$ \\
\hline
\end{tabular}

through surgical procedures, trauma, ridge resorption or traumatic tooth extraction. ${ }^{16}$ The terms used to describe these appliances include flange prosthesis, gingival veneer prosthesis, removable gingival veneer, acrylic gingival veneer, acrylic periodontal veneer, removable gingival extension and gingival mask. ${ }^{17-23}$ As 'gingival veneers' constructed from porcelain for single tooth units were described in the previous section, the authors feel that 'gingival prosthesis' is the most appropriate term. Gingival prostheses can be produced from either acrylic or silicone and are retained using undercuts both interdentally and distal to the terminal abutments. ${ }^{16,23,24}$ They can be constructed at the chair side or indirectly. ${ }^{16,17}$ The indirect technique requires an impression that captures the interproximal spaces and the full depth of the sulcus for the span of the planned prosthesis ideally using a special tray (Fig. 13). ${ }^{23}$ Where patients have poor oral hygiene or a high caries rate the provision of a gingival prosthesis is contraindicated until any ongoing disease is stabilised..$^{25}$ In patients with a low labial frenum a frenectomy can be considered before provision, otherwise a midline fracture of the thin acrylic in this area may be more likely. ${ }^{24}$ Where loss of interdental papillae is marked, air escape through interdental spaces which compromises phonetics can be prevented with a gingival prosthesis. ${ }^{17}$ Dentine hypersensitivity is a recognised complication of periodontal treatment; a gingival prosthesis can be used to apply and maintain

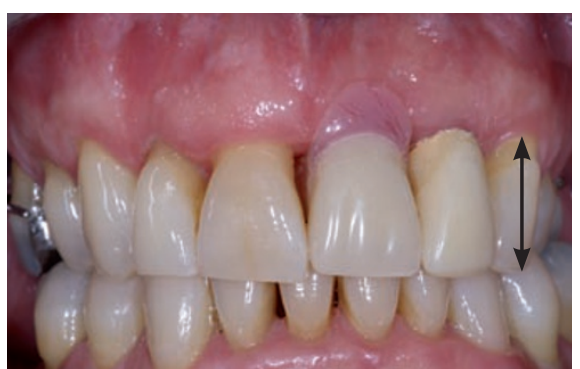

Fig. 6 Patient presenting with a removable partial denture replacing 21 and a temporary crown on 22

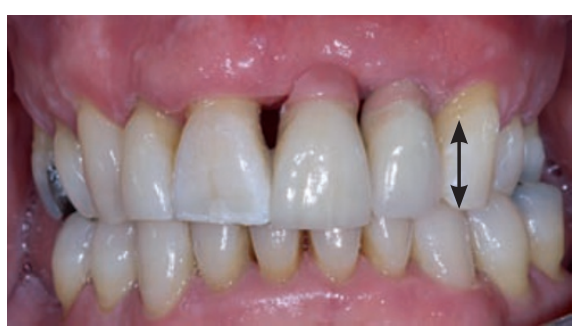

Fig. 7 The denture was replaced with a resin bonded bridge cantilevered from 11 and the 22 was definitively restored with a metal ceramic crown. Both restorations had gingivally coloured porcelain incorporated. Note the black arrows illustrating the difference in incisal-cervical length of the temporary crown in comparison to the final restoration. The definitive restoration illustrates how a small amount of gingivally coloured ceramic can improve aesthetic proportions

contact of desensitising agents against root dentine to help alleviate symptoms. ${ }^{23}$ Similarly, the use of a gingival prosthesis in the management of patients with desquamative gingivitis that is associated with conditions such as lichen planus, bullous dermatoses and plasma cell gingivitis has also been described. ${ }^{26}$ Symptoms can be alleviated by using a gingival prosthesis

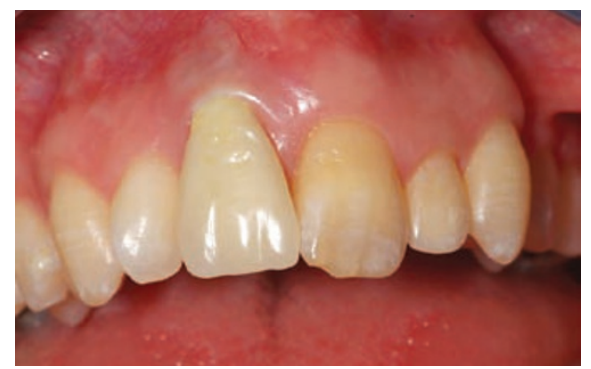

Fig. 8 Patient presenting with recession associated with the $11 \mathrm{implant}$

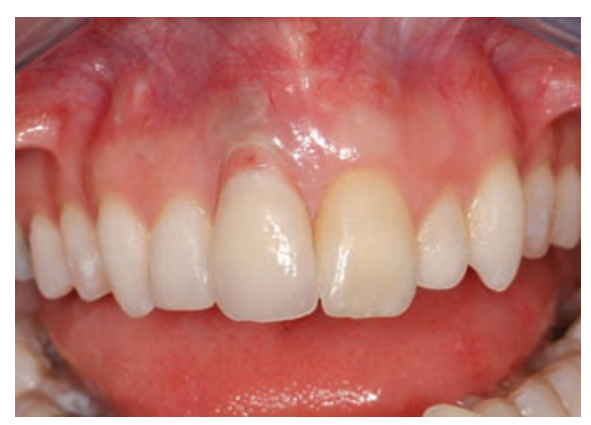

Fig. 9 The definitive porcelain restoration with gingivally coloured porcelain. Note the thinning of porcelain cervically to allow for cleansability but resulting in slight show through of the abutment

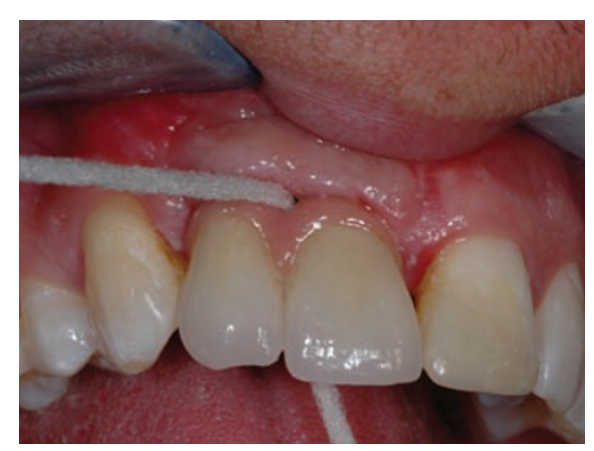

Fig. 10 Linked implant crowns 11 and 12. Sufficient space was incorporated into the prosthesis to allow for flossing while also creating a 'pseudopapilla' 


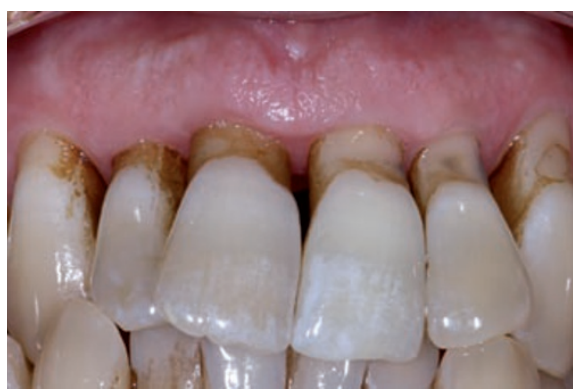

Fig. 11 This patient presented complaining of 'long teeth' and air and fluid escaping from between the anterior teeth

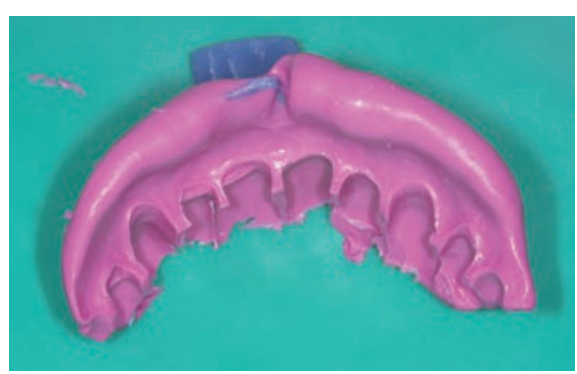

Fig. 12 A special tray was constructed to capture the buccal interproximal spaces and gingival profile

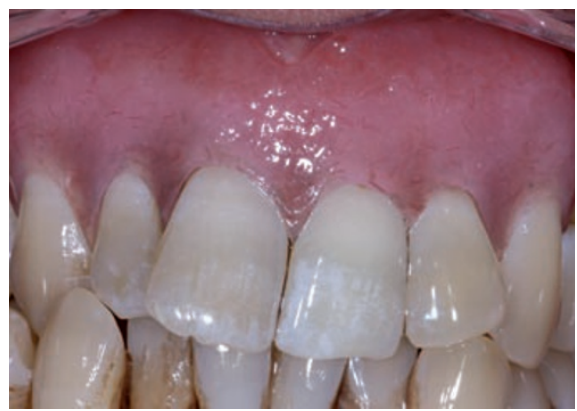

Fig. 13 A gingival prosthesis was constructed providing the patient with improved aesthetics

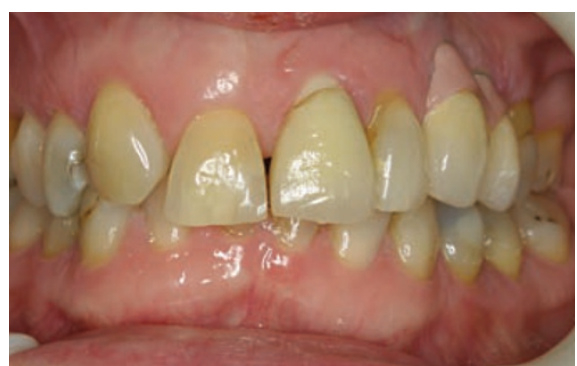

Fig. 14 This patient presented complaining of gingival height mismatch between all of the anterior teeth. This was due to variation in the sizes of teeth (13 in 12 position), recession defect on the 21 and implant bridgework in the 23-24 area

to hold therapeutic steroid medicaments against the affected mucosa. ${ }^{26}$ Where patients are prone to root caries, such as those who have undergone radiotherapy for head and neck cancer, a gingival prosthesis could be used to deliver

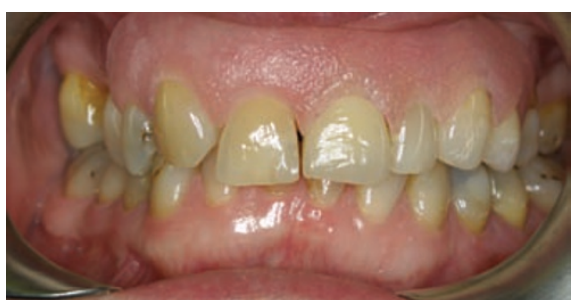

Fig. 15 The patient was treated with a gingival prosthesis. Note the soft tissue aesthetics and the stippling incorporated into the acrylic

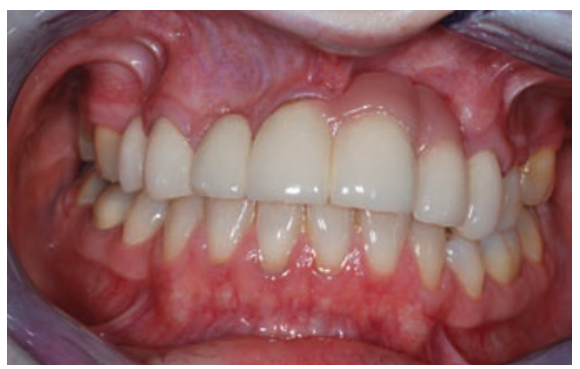

Fig. 16 Patient presenting with fixed bridgework spanning 14 to 23 . Gingivally coloured porcelain was overextended in the 21-22 region which compromised the patientis ability to clean under the pontics

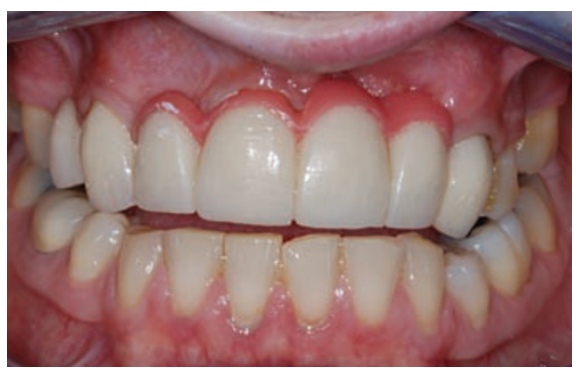

Fig. 17 Once the bridgework had been removed, a lab-made provisional bridge constructed from traditional and gingivally coloured composite was fitted. This interim prosthesis provided the patient, the clinician and technician an opportunity to evaluate the aesthetics of the proposed restoration while also gauging cleansability of the bridge design

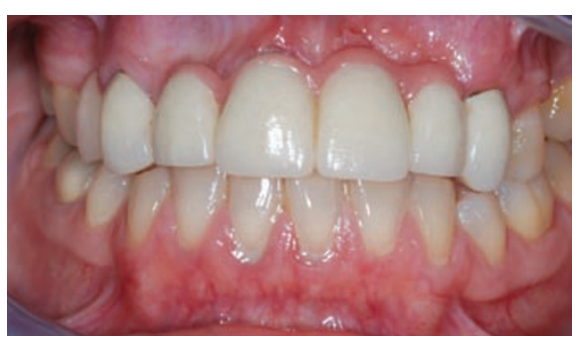

Fig. 18 Definitive bridgework. Note the reduced extension of gingival porcelain facilitating access for hygiene

fluoride formulations in a similar fashion and so aid in remineralising early carious lesions. ${ }^{27}$

Where there has been marked vertical resorption of the edentulous ridge post extraction, the combination of a conventional bridge and a gingival prosthesis has been reported..$^{22}$ In contrast to engaging interproximal undercuts the methods described for retention of gingival prostheses in combination with a bridge have included the use of pins and precision attachments. ${ }^{16,22}$ The use of pins as opposed to attachments for retention could be considered advantageous due to the relative ease with which the removable component can be replaced by simply taking a new impression. If the removable portion is retained by an attachment, the dismantling of the whole bridge and a new fixed and removable restoration may be required even if only the gingival portion requires replacement. As it is likely that a gingival prosthesis will require replacement due to loss of retention or discolouration of the acrylic, the ease with which a new prosthesis can be constructed is an important consideration.

\section{Gingival porcelain on fixed bridgework}

Where multiple teeth are to be replaced by a fixed prosthesis, the creation of harmonious gingival levels between edentulous spaces and implant or tooth abutments can be difficult (Fig. 1). The achievement of ideal gingival levels may not be required in low smile line presentation or where gingival aesthetics themselves are not a priority for the patient. If large edentulous spans are present the soft tissue topography in vertical, horizontal and combined planes can make implant placement and subsequent restoration challenging. Indeed implant retained bridgework in the aesthetic zone where inadequate soft tissue profile is present can result in inverted tooth axes, incorrect tooth proportions, inverted smile lines or rectangular teeth with long contact points. ${ }^{28}$ Surgical approaches to this lack of tissue volume include distraction osteogenesis and/or the use of onlay bone grafts. Connective tissue roll grafts to increase soft tissue volume may also suffice. ${ }^{29}$ These procedures carry significant morbidity and may not always provide the ideal topography for implant placement or pontic emergence in the aesthetic zone. ${ }^{30}$ Where marked vertical defects in edentulous spaces are present, gingivally coloured materials can be used in the provision of fixed bridgework to improve vertical and horizontal 


\begin{tabular}{|c|c|c|}
\hline Feature & $\begin{array}{l}\text { Removable gingival prosthesis in } \\
\text { combination with fixed bridgework }\end{array}$ & $\begin{array}{l}\text { Fixed prosthesis incorporating gingivally coloured } \\
\text { ceramic in edentulous spans }\end{array}$ \\
\hline Fabrication & $\begin{array}{l}\text { Relatively easy once definitive bridgework is } \\
\text { fitted. Buccal impression (Fig. 12) in addition } \\
\text { to accurate shade taking }\end{array}$ & $\begin{array}{l}\text { More complicated due to the demands of providing } \\
\text { ceramic work for both abutment and pontic components } \\
\text { of the bridgework }\end{array}$ \\
\hline Retention and function & $\begin{array}{l}\text { Prosthesis is retained by interproximal undercuts } \\
\text { which need to be planned in advance }\end{array}$ & Incorporated into bridgework \\
\hline Aesthetics & $\begin{array}{l}\text { Larger volumes of tissue can be replaced. } \\
\text { Spacing between the gingival prosthesis and } \\
\text { bridge pontics maybe present. Gingival colour } \\
\text { matching may be easier to achieve. Prosthesis } \\
\text { can be feathered into transition zone }\end{array}$ & $\begin{array}{l}\text { Aesthetics may be compromised as the prosthesis needs } \\
\text { to be cleansable and so extensive ridge lapping needs } \\
\text { to be avoided (Fig. 16). Gingival colour may be hard to } \\
\text { achieve. Feather edge not possible }\end{array}$ \\
\hline Refurbishment & $\begin{array}{l}\text { Can be modified as tissue changes. A new } \\
\text { gingival prosthesis can be constructed } \\
\text { relatively easily }\end{array}$ & $\begin{array}{l}\text { If tissue changes occur such as further ridge resorption } \\
\text { modification would be difficult and a new bridge may } \\
\text { be required }\end{array}$ \\
\hline Hygiene & $\begin{array}{l}\text { Patients must be advised to remove prosthesis } \\
\text { for hygiene procedures }\end{array}$ & $\begin{array}{l}\text { Can be difficult to keep plaque free; patients require } \\
\text { appropriate oral hygiene instruction and review (Fig. 10) }\end{array}$ \\
\hline Complications & $\begin{array}{l}\text { Prosthesis can be prone to fracture especially } \\
\text { in the midline. The need to cover the whole } \\
\text { of the aesthetic zone buccal alveolus may } \\
\text { result in aesthetically unacceptable additional } \\
\text { support to the lip. Has the disadvantage of } \\
\text { being removable which may be unacceptable } \\
\text { to some patients }\end{array}$ & $\begin{array}{l}\text { If further gingival changes occur around abutment teeth } \\
\text { after the restoration has been fitted, a new restoration } \\
\text { may be required to maintain gingival harmony }\end{array}$ \\
\hline
\end{tabular}

pontic proportions (Figs. 10, 16-18). Indeed patients who have undergone surgical procedures to improve soft tissue topography may still require the use of gingivally coloured porcelain to optimise aesthetics of the final restoration. ${ }^{30}$ The awareness of limitations of adjunctive surgical procedures should be borne in mind and incorporation of gingival porcelain in the final restoration should be considered at the planning stage. ${ }^{28}$ This planning can range from a diagnostic wax-up to CT scanning for prospective gingival and tooth restorations. ${ }^{31}$ The reduction in morbidity, time and cost for patients when providing gingival porcelain as opposed to bone grafting is considered advantageous for patients undergoing implant rehabilitation in the aesthetic zone. ${ }^{28}$ Additional benefits include the use of the gingival porcelain ridge lap to aid in lip support and phonetics. ${ }^{28}$ Where multiple implants have been placed optimally the use of gingivally coloured porcelain can provide the appearance of interdental papilla (Fig. 10). This approach can be difficult to maintain where implant pier abutments are present or the implants are positioned in close proximity. Masking of the vertical defect and improvement of aesthetics needs to be balanced against the ability to clean under associated pontics (Figs 10, 16-18). In patients with a high smile line the junction of the gingivally coloured porcelain with the natural gingival tissue may be noticeable, which may not be acceptable for the aesthetically aware patient. Where implant position is relatively palatal in the upper anterior region, the bulk of gingivally coloured porcelain may provide an extensive ridge lap which can be difficult to clean. These difficulties can be identified and addressed before definitive restoration by constructing a laboratory temporary with gingival material incorporated for evaluation by the patient, dentist and technical staff (Fig. 17).

The relative advantages and disadvantages of bridgework in combination with a gingival prosthesis in comparison to bridgework with gingivally coloured porcelain are outlined in Table 2.

\section{MANAGEMENT OF SOFT TISSUE AESTHETICS IN THE DENTURE PATIENT}

In the part dentate patient where there are limited teeth remaining in unfavourable configuration to support a fixed restoration or a conventional partial denture a swing-lock partial denture can be considered. ${ }^{32}$ Where gingival tissue loss is present on the remaining teeth, the swing-lock component of the prosthesis can carry a gingival component to optimise aesthetics (Figs 19 and 20).

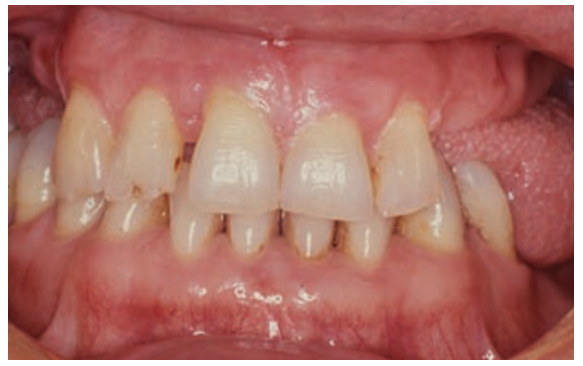

Fig. 19 Patient presenting with recession of the anterior segment resulting in varying gingival heights due to toothbrush abrasion

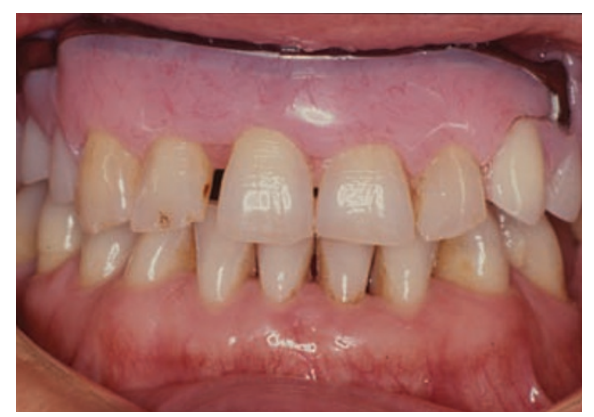

Fig. 20 A denture was provided which incorporated a swing lock component improving retention while also optimizing gingival aesthetics

When considering aesthetics in complete denture construction the characterisation of the denture base, the use of appropriate root contouring and stippling have been identified as features in the production of a natural looking complete denture (Fig. 21). ${ }^{33}$ Where patients wish to have a prosthesis that is similar to their 


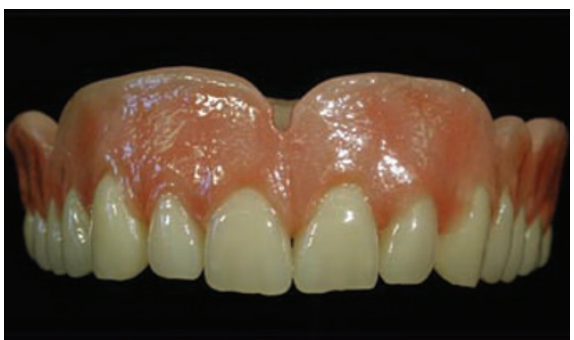

Fig. 21 Complete maxillary dentures recreating natural gingival appearance with realistic gingival architecture, stippling and root contouring

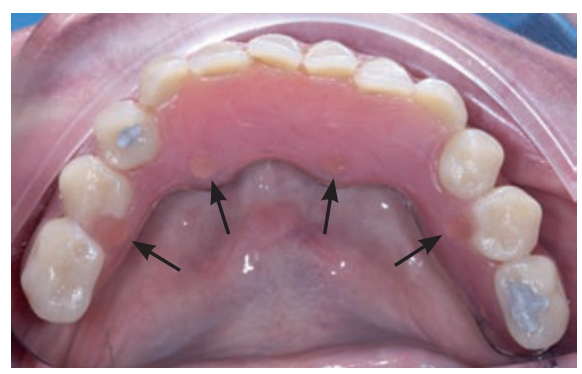

Fig. 22 Mandibular fixed prosthesis illustrating the use of gingivally coloured composite (black arrows) in the implant screw access holes and the amalgam restorations placed in teeth to give a more natural appearance

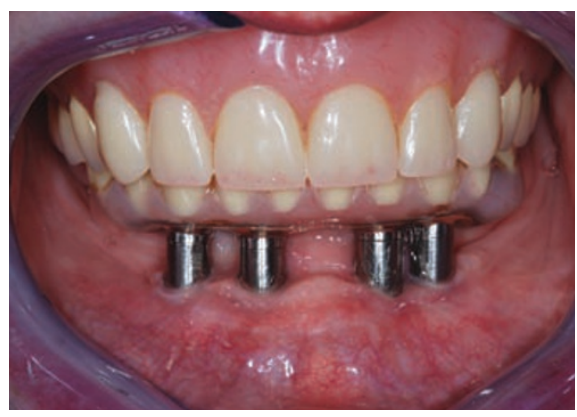

Fig. 23 Fixed implant prosthesis supported by four implan. The patient complained of exposed metal work from the abutments in addition to air, saliva and food escape between the units

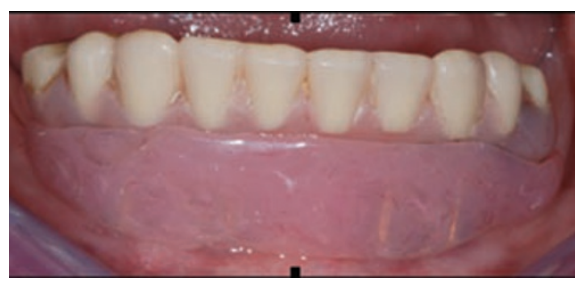

Fig. 24 The use of a acrylic insert to mask the abutments and so providing a barrier and lip support

previous aging dentition the incorporation of staining into the denture teeth in addition to pseudo recession and gingival inflammation has also been described. ${ }^{34}$ In creating an aesthetic denture where the previous natural dentition has been removed recently, pre-extraction records,

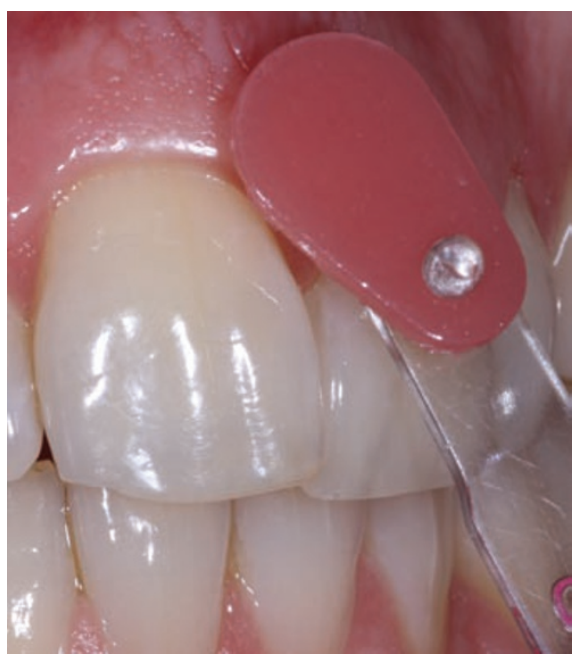

Fig. 25 Traditional tab enclosed in gingival porcelain kits

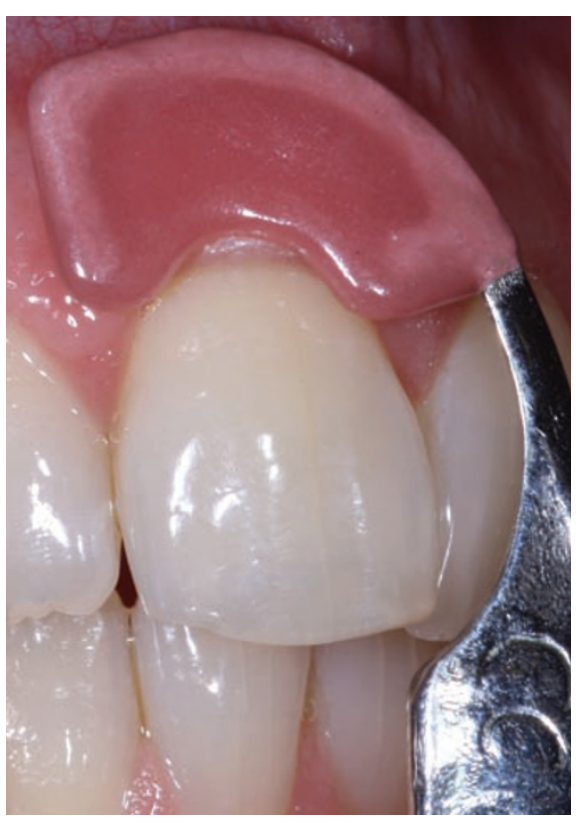

Fig. 26 Laboratory constructed tab

mimicking the arc of the gingival margin to aid in shade taking

photos and study models can be used to reproduce tooth positions and gingival contours and dimensions in immediate replacement dentures and the definitive prosthesis. ${ }^{34}$ Where patients are especially sensitive to the appearance of fixed implant prosthesis, standard restorative materials and gingivally coloured composite can be used to customise restorations (Fig. 22). Optimal masking of abutment screw holes located lingual to prosthetic teeth can be achieved by using gingivally coloured composite as opposed to tooth coloured composite resin (Fig. 22). Previously mentioned problems encountered with phonetics of patients with longstanding periodontal disease can also manifest similarly in patients with a fixed implant prosthesis (Fig. 23). ${ }^{35}$ Masking of multi-unit abutments in addition to minimising unwanted air escape during speech can be achieved by using removable indirectly or directly constructed gingival prosthesis (Fig. 24). The clinical and laboratory stages for these restorations are similar to those of gingival prostheses (Figs 11-15).

\section{TECHNICIAN-CLINICIAN INTERFACE}

The importance of communicating effectively with technician colleagues is clearly important in providing both fixed and removable prostheses. ${ }^{36,37}$ Technician involvement at the planning stages of a proposed restoration that requires a gingival component has been recommended. ${ }^{31}$ Where ridge lap design is critical for aesthetics, technician input is important to produce an aesthetic and cleansable result. ${ }^{28}$ Discussion with technician colleagues using appropriate information such as study models on the prosthesis design before fabrication may aid in providing an aesthetic and cleansable result.

The ability to accurately record shade for a subsequent restoration is a difficult task for both dentist and technician. ${ }^{38}$ Problems in producing the optimal shade when constructing fixed gingivally coloured ceramic restorations have been reported. ${ }^{13}$ For conventional shade taking, the use of photography, diagrams, multiple shade recordings and electronic colour measure devices can help in achieving optimal shade, although the latter have not been developed for gingival shades. ${ }^{39}$ As the provision of gingivally coloured restorations are relatively new, adapted shade tabs may help to make shade recording more predictable and accurate (Figs 25 and 26). Where technicians are present on-site, a joint consultation with the dentist and patient may aid in the shade-taking process.

\section{CONCLUSION}

Where recession is localised to a single tooth and root coverage surgery is not indicated, the use of adhesive direct or indirect materials can be considered. Where multiple recession defects are present in stabilised periodontal patients, the use of a gingival prosthesis can be provided relatively easily with a predictable result. 
In patients requiring fixed restoration in the aesthetic zone, the use of gingivally coloured porcelain can help in recreating natural tooth proportions. As with all restorations, the involvement of technical colleagues at an early stage in the planning is recommended.

As the prosthetic techniques described in this paper are minimally invasive with low morbidity, they may provide realistic alternatives to surgery for patients concerned about soft tissue aesthetics.

The authors would like to thank Mr. David Hollisey-Mclean (Morriston Hospital, Swansea) and Mr. Stuart Graham-Scott (Newcastle Dental Hospital) for the majority of laboratory work presented in this publication.

1. Işiksal E, Hazar S, Akyalçin S. Smile esthetics: perception and comparison of treated and untreated smiles. Am J Orthod Dentofacial Orthop 2006; 129: 8-16

2. LaVacca M I, Tarnow D P, Cisneros G J. Interdental papilla length and the perception of aesthetics. Pract Proced Aesthet Dent 2005; 17: 405-412.

3. Clark D. "Restoratively driven papilla regeneration: correcting the dreaded 'black triangle'". Tex Dent J 2008; 125: 1112-1115.

4. Wennström J L, Pini Prato G P. Mucogingiva therapy. In Lindhe J, Karring T, Lang N P (eds) Clinical periodontology and implant dentistry. 3rd ed. pp 550-596. Copenhagen: Munksgaard, 1997.

5. Boronat A, Carrillo C, Penarrocha M, Pennarocha M. Dental implants placed simultaneously with bone grafts in horizontal defects: a clinical retrospective study with 37 patients. Int J Oral Maxillofac Implants 2010; 25: 189-196.

6. Breault L G, Shakespeare R C, Fowler E B. Enhanced fixed prosthetics with a connective tissue ridge augmentation. Gen Dent 1999; 47: 618-622.

7. Capri D, Albehbehani Y, Smukler H. Augmentation of an anterior edentulous ridge for fixed prosthodontics with combined use of orthodontics and surgery: a clinical report. J Prosthet Dent 2003; 90: $111-115$.

8. Donovan T E. Clinical management of root caries. $J$ Indiana Dent Assoc 2009; 88: 23-24.

9. Tammaro S, Wennström J L, Bergenholtz G.
Root-dentin sensitivity following non-surgical periodontal treatment. J Clin Periodonto/ 2000; 27: 690-697.

10. Zalkind M, Hochman N. Alternative method of conservative esthetic treatment for gingival recession. J Prosthet Dent 1997; 77: 561-563.

11. Blank L W, Caffesse R G, Charbeneau G T. The gingival response to well-finished composite resin restorations: a 28-month report. J Prosthet Dent 1981: 46: 157-160.

12. McCoy $R B$, Anderson M H, Lepe $X$, Johnson $G H$. Clinical success of class $V$ composite resin restorations without mechanical retention. JAm Dent Assoc 1998; 129: 593-599.

13. Capa N. An alternative treatment approach to gingival recession: gingiva-colored partial porcelain veneers: a clinical report. J Prosthet Dent 2007 98: 82-84.

14. Hannon S M, Colvin C J, Zurek DJ. Selective use of gingival-toned ceramics: case reports. Quintessence Int 1994: 25: 233-238.

15. Kamalakidis $S$, Paniz G, Kang $K H_{\text {, Hirayama }} H$. Nonsurgical management of soft tissue deficiencies for anterior single implant-supported restorations: a clinical report. J Prosthet Dent 2007; 97: 1-5.

16. Barzilay I, Irene T. Gingival prostheses-a review. J Can Dent Assoc 2003; 69: 74-78.

17. Blair F M, Thomason J M, Smith D G. The flange prosthesis. Dent Update 1996; 23: 196-199.

18. Ellis S G, Sharma P, Harris I R. Case report: aesthetic management of a localised periodontal defect with a gingival veneer prosthesis. Eur J Prosthodont Restor Dent 2000; 8: 23-26.

19. Matsuura T. [A clinical report of application of implant-supported fixed partial denture with a removable gingival veneer to a patient who has severe resorption of maxillary anterior ridge]. Nihon Hotetsu Shika Gakkai Zasshi 2008; 52: 408-411.

20. Mekayarajjananonth T, Kiat-amnuay $S$, Sooksuntisakoonchai N, Salinas T J. The functional and esthetic deficit replaced with an acrylic resin gingival veneer. Quintessence Int 2002; 33: 91-94.

21. Ghandour A A. A functional acrylic periodontal veneer (case report). Odontostomatol Trop 1989; 12: 75-76.

22. Cura C, Saraçoglu A, Cötert H S. Alternative method for connecting a removable gingival extension and fixed partial denture: a clinical report. J Prosthet Dent 2002; 88: 1-3.

23. Greene PR. The flexible gingival mask: an aesthetic solution in periodontal practice. Br Dent J 1998; 184: 536-540.

24. L'Estrange P R, Strahan J D. The wearing of acrylic periodontal veneers. Br Dent J 1970; 128: 193-194. 25. Hickey B, Jauhar S. Gingival veneers. Dent Update
2009; 36: 422-4: 426, 428.

26. Wray D, McCord J F. Labial veneers in the management of desquamative gingivitis. Oral Surg Oral Med Oral Pathol 1987; 64: 41-42.

27. Aguiar G P, Jham B C, Magalhães C S, Sensi L G, Freire A R. A review of the biological and clinical aspects of radiation caries. J Contemp Dent Pract 2009; 10: 83-89.

28. Coachman C, Salama M, Garber D, Calamita M, Salama H, Cabral G. Prosthetic gingival reconstruction in a fixed partial restoration. Part 1: introduction to artificial gingiva as an alternative therapy. Int J Periodontics Restorative Dent 2009; 29: 471-477.

29. Triplett R G, Schow S R, Laskin D M. Oral and maxillofacial surgery advances in implant dentistry. Int J Oral Maxillofac Implants 2000; 15: 47-55.

30. Palmer R M, Palmer P J, Newton J T. Dealing with esthetic demands in the anterior maxilla. Periodontol 2000 2003; 33: 105-118.

31. Salama M, Coachman C, Garber D, Calamita M Salama H, Cabral G. Prosthetic gingival reconstruction in the fixed partial restoration. Part 2: diagnosis and treatment planning. Int J Periodontics Restorative Dent 2009; 29: 573-581.

32. Lynch $C D$, Allen P F. The swing-lock denture: its use in conventional removable partial denture prosthodontics. Dent Update 2004; 31: 506-508.

33. Waliszewski M, Shor A, Brudvik J, Raigrodski A J. A survey of edentulous patient preference among different denture esthetic concepts. J Esthet Restor Dent 2006; 18: 352-368.

34. Ali A, Hollisey-McLean D. Improving aesthetics in patients with complete dentures. Dent Update 1999; 26: 198-202.

35. Graser G N, Myers M L, Iranpour B. Resolving esthetic and phonetic problems associated with maxillary implant-supported prostheses. A clinical report. J Prosthet Dent 1989; 62: 376-378.

36. Afsharzand Z, Rashedi B, Petropoulos V C. Dentist communication with the dental laboratory for prosthodontic treatment using implants. J Prosthodont 2006; 15: 202-207.

37. Lynch C D, Allen P F. Quality of written prescriptions and master impressions for fixed and removable prosthodontics: a comparative study. Br Dent J 2005: 198: 17-20.

38. Derbabian K, Marzola R, Donovan T E, Arcidiacono $A$. The science of communicating the art of esthetic dentistry. Part III: precise shade communication. J Esthet Restor Dent 2001: 13: 154-162.

39. Khurana R, Tredwin C J, Weisbloom M, Moles D R. A clinical evaluation of the individual repeatability of three commercially available colour measuring devices. Br Dent J 2007; 203: 675-680. 